\title{
Hiroshi Sugimotos havbilleder
}

Af Ph.d.-studerende Lars Kiel Bertelsen, Center for Kulturforskning, Aarhus Universitet

Vi fascineres af enhed, kun enhed forekommer os rationel. Vi foragter sanserne, fordi deres information når os $i$ byger...

Michel Serres

Når jeg ser på fotografier i dag, hæfter der en sær fremmedhed ved dem. Jeg tager dem ikke mere for givet, - ikke mere end jeg tager et rokokomaleri for givet. Fotografiet er som genre blevet dét, kunsthistorikeren Norman Bryson i en anden sammenhæng har kaldt en "eksotisk blomst."1 Det har mistet sin særstatus i billedernes store familie og står nu side om side med de andre billedtyper, frataget sin "naturlige" autoritet, en autoritet som selvfølgelig aldrig var naturlig, men derimod udtryk for et helt igennem ideologisk forsøg på at trække en uoverskridelig grænse mellem på den ene side finkulturens malerier, skulpturer og tegninger, og på den anden side massekulturens effektive, men banale fotografier. Den grænse er i dag brudt endegyldigt sammen, og fotografiet er blevet eksotisk, sært. Vi kan ikke længere se på fotografiske billeder med naive, realistiske briller, men må betragte dem som visuelle konstruktioner på linie med malerier og tegninger.

Den japanskfødte kunstner Hiroshi Sugimotos (f. 1948) billeder er - skjult bag den tilsyneladende realistiske transparens (også transparens kan skjule) - ekstreme fotografiske konstruktioner, og Sugimoto udtrykker selv et åbenlyst slægtsskab med den klassiske malertradition. ${ }^{2}$ Mest kendt er han for to billedserier der viser biografsale og drive-in biografer, optaget med lukkertider lige så lange som de viste spillefilm. Resultatet af denne særegne fotografiske teknik er billeder der synes at have opsuget 
den forløbne tid i sit fysiske stof, som om tiden selv med ét var blevet syn-lig. Det er paradoksale billeder, for selvfølgelig kan tiden ikke vises, højst antydes ved at vise det, der sker i den (alt synligt kommer til syne på baggrund af tiden; tiden selv er usynlig). Også Sugimotos serie af fotografier fra voksmuseer og naturhistoriske udstillingsmontrer er paradoksale. Her ser vi museernes opstillinger af udstoppede dyr og voksmuseernes udklædte menneskefigurer afbilledet med en ekstrem og urovækkende fotografisk præcision, der lader to forskellige illusionismer møde hinanden: Tableau'ernes illusionisme og fotografiets illusionisme. Resultatet er en særlig uafgørlighed, som er karakteristisk for Sugimotos billedverden.

Sugimotos serie af Seascapes, havbilleder, som her præsenteres med to fotografier fra Kort- og Billedafdelingens samling, Det kongelige Bibliotek, er optaget i årene 1989-94 og består i sammenligning med biograf- og tableau-billederne af mere traditionelt optagede fotografier af forskellige have: det Indiske Ocean, den Engelske Kanal, Stillehavet, Østersøen... Alle er komponeret over samme minimalistiske læst: Horisontlinien er altid placeret præcist i midten af billederne som er optaget i sort/ hvid med det forhåndenværende lys og altid i samme format. Men selv om havbillederne i højere grad følger de gængse fotografiske konventioner, og ikke som i biografbillederne udstrækker den fotografiske eksponeringstid til det groteske, eller som i tableaubillederne vælger at fotografere illusioner om virkelighed snarere end virkeligheden selv, ja så er også Sugimotos Seascapes paradoksale billeder. De er skræmmende at stå overfor, og de fremkalder en svimmelhed der minder om dén, havet selv kan fremkalde. Alligevel er effekten tydeligvis forårsaget af det faktum at vi her står over for billeder af havet, ikke havet selv. Men hvori består da havbilledernes paradoks?

Måske er årsagen til vor foruroligelse at Sugimoto også i havbillederne angriber eller bearbejder en væsentlig fotografisk konvention, nemlig en bestemt forestilling om enhed, som vi straks vil vende tilbage til. Først må vi nemlig konstatere, at skønt hans billeder ved første øjekast virker endog særdeles fotografiske (de opfylder en række af de krav vi normalt stiller til fotografier, såsom detaljeskarphed, perspektivisk gengivelse osv.), så er der alligevel tale om billeder som på forskellig vis udfordrer centrale aspekter ved foto-grafiet og på den måde problematiserer vor forestilling om, hvad fotografiet overhovedet er for en størrelse. Således har vi allerede 
set hvordan Sugimoto i biografbillederne vender den almindeligt udbredte forestilling om fotografiet som snapshot på hovedet, og i stedet præsenterer os for en slags "slow-shots". Herved demonstreres det med stor tydelighed at enhver fotografisk teknik på én gang skjuler og synliggør: Som timerne går fæstnes motivets ubevægelige partier på den lysfølsomme

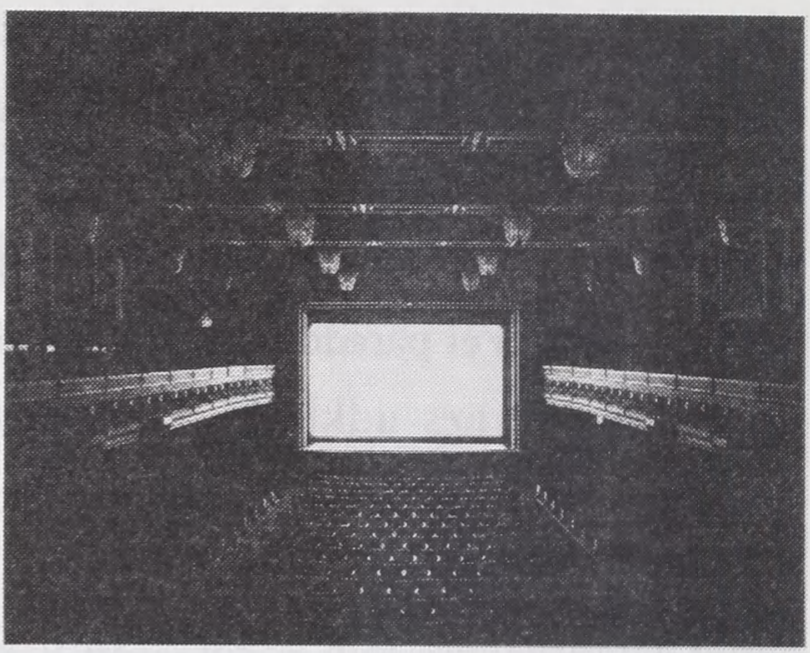

Regency, San Francisco, 1992 film, mens det, vi normalt forstår som biografens egentlige motiv, nemlig filmen, på grund af dens stadige forandring bliver usynlig og forsvinder $\mathrm{i}$ en hvid tåge. Pointen er naturligvis at heller ikke det traditionelle snapshot registrerer hele virkeligheden, men kun et bestemt udsnit af den, nemlig det register som snapshottets korte lukkertid filtrerer. Også snapshottet rummer usynligheder, som vi imidlertid overser fordi vi har vænnet os til det. Det er blevet en konvention.

I fotografierne fra de naturhistoriske tableauer og vokskabinetterne er det vor forestilling om fotografiets virkelighedsgengivelse der stilles spørgsmål ved. Sugimoto "snyder" ikke; han har jo i en vis forstand fotograferet virkeligheden, nemlig vokskabinettets virkelighed, og det er ikke ham, men os, der forestiller os at det er noget andet vi ser på billederne. Hvad disse billeder viser er således at fotografiet på en og samme gang er fuldstændigt troværdigt og fuldstændigt løgnagtigt. Hvad vi ser er nok en slags aftryk af en virkelighed, men ikke sandheden om denne virkelighed. Sandhed er nemlig grundlæggende et spøgsmål om enighed, ikke en egenskab ved billederne eller tingene. Vi kan sige at sandhed er en variabel relation mellem fænomenerne, som vi enes om at kalde sandhed. Igen er pointen naturligvis at det også gælder det traditionelle fotografi. Ethvert fotografi udgør et spor efter noget, men ikke nødvendigvis efter dét, vi tror at se. Selv om det virker som pernittengrynet teknologifiksering, så er det værd at bemærke at fotografier strengt taget slet ikke er aftryk af tingene, men derimod af de lysstråler som reflekteres fra dem. Det gør faktisk en forskel! Det betyder nemlig, at lysstrålerne på deres vej fra objekterne til den lysfølsomme film må "styres" eller "programmeres."

I det traditionelle fotografi er linsen sådan et styretøj eller program, der strukturerer 


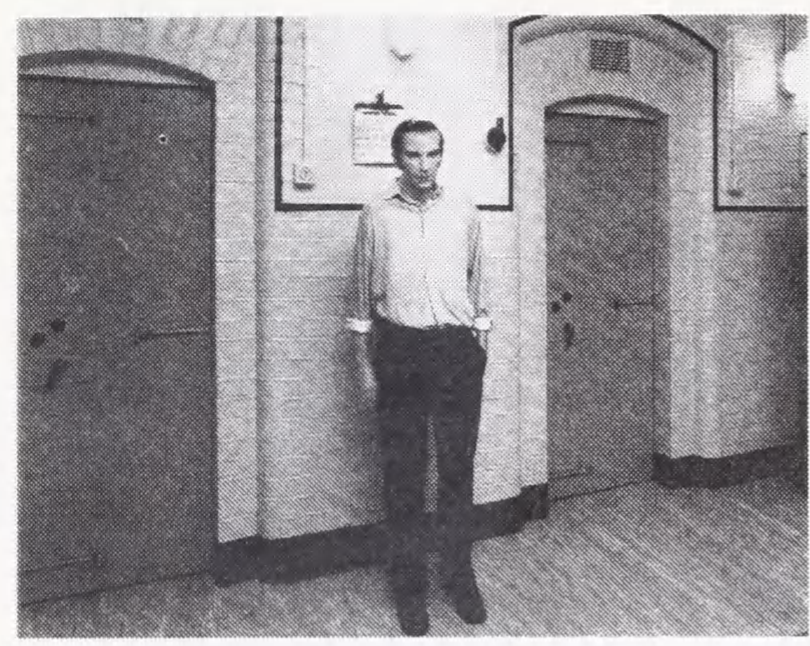

The St. Albans Poisoner, 1994

lyset efter det klassiske matematiske perspektiv. Vi har vænnet os til dette perspektiv i en grad, så vi i dag tror at det er naturligt, men som allerede kunsthistorikeren Erwin Panofsky sagde i begyndelsen af dette århundrede, så er perspektivet selv en "symbolsk form." 3 I forhold til det "naturlige" syn (hvad det så end er for noget) bygger det på en lang række reduktioner og abstraktioner, hvoraf den væsentligste er, at hvor vi (normalt) ser med to øjne, da forudsætter det perspektiviske billede et statisk, en-øjet blik. Perspektivet blev opfundet samtidig med de moderne naturvidenskaber, og er sidenhen blevet vævet uløseligt sammen med disse videnskabers måder at se på verden på. Det repræsenterer et objektiverende, analytisk snit gennem synsfeltet, en slags præparat af det synlige, og udgør således en utopisk drøm om synet snarere end synet selv. Vore menneskelige, levende og bevægelige øjne ser simpelthen ikke linearperspektivisk! De er en del af en levende, bevægelig, sansende krop der kaster begærlige projektioner ud i verden i lige så høj grad som den modtager passive synsindtryk...

Men havbillederne da, på hvilken måde kan de siges at bearbejde eller kritisere vor forestilling om fotografiet, og hvordan kan man overhovedet sige noget om disse tavse, tågede landskaber? Som sagt tror jeg at det er frugtbart at anskue også disse billeder som selvrefleksive kommentarer til fotografiets konventioner, til vor forestilling om hvad et fotografi er for noget. Og som sagt tror jeg at det i Seascapeserien handler om en bestemt konvention om enhed, der har gennemsyret fotografiet næsten lige siden dets fremkomst i 1830'erne.

Da fotografiet endnu var ganske nyt, begejstredes udøverne over teknikkens evne til at gengive meget detaljerige motiver minutiøst. Komplekse motiver såsom trækroner, murværk og høstakke som i tegne- og malerkunsten var blevet gengivet med en syntetiserende, altså samlende, abstraktion, kunne pludselig gengives på en måde så det syntes som om hvert eneste blad, hver eneste mursten og hvert eneste strå trådte frem for sig, skelnelig fra alle de andre blade, mursten og strå. Mursten 


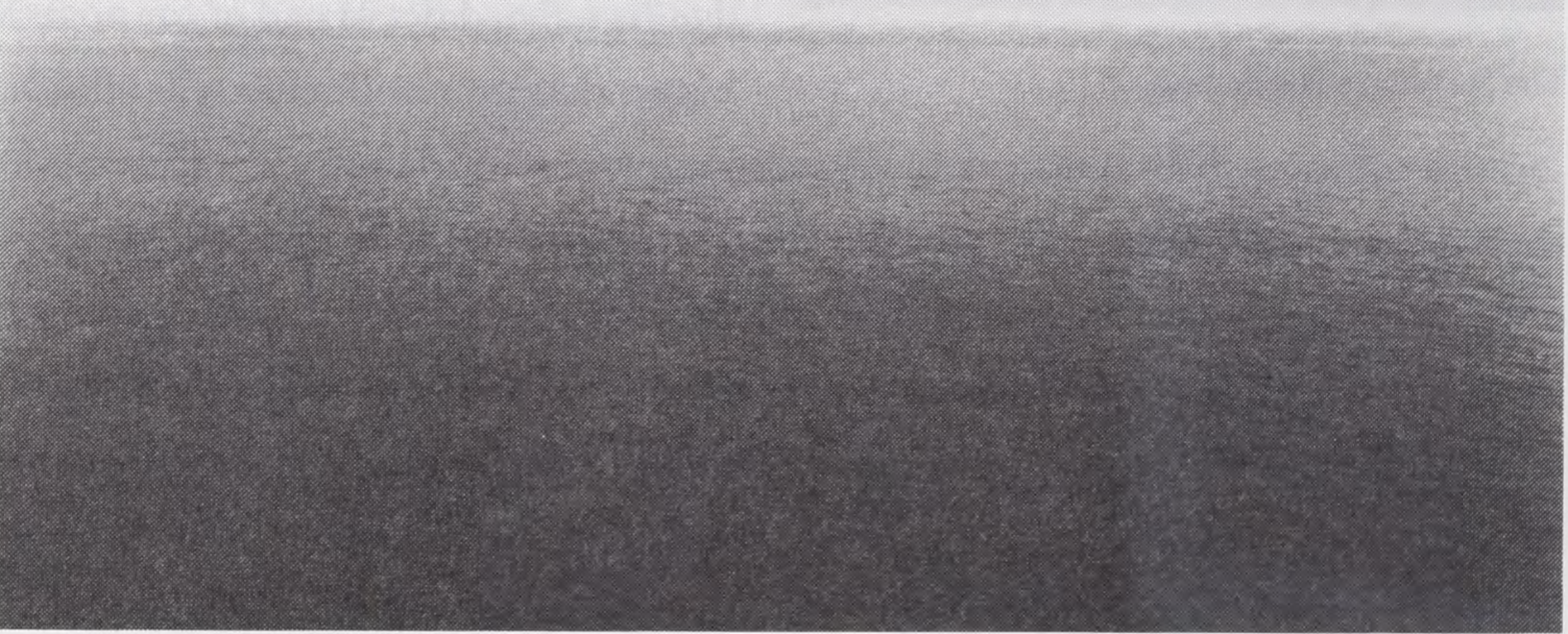

Hiroshi Sugimoto. Irish Sea, Isle of Man 1, 1990. Gelatine sølvtryk, 508 x 610 mm. 5/25.

og tegltage blev en slags metafor for det nye mediums fantastiske egenskaber, og en kommentator skrev siden i tilbageblik:

"Alle og enhver ville fastholde udsigten fra deres vinduer, og dén der i første forsøg blot fik en silhouet af hustagene imod himlen var heldig. Han gik i ekstase over en skorsten, talte igen og igen teglene og murstenene, var lamslået over endog at se fugerne imellem stenene, - kort sagt: Teknikken var så ny at selv det ynkeligste aftryk gav ham usigelig fryd." 4

Imidlertid gik det hurtigt op for fotograferne at denne evne til præcis detaljeoverførsel, som er så karakteristisk for mediet, ikke i sig selv var garant for det fotografiske billede. Der skulle noget mere til for at få et genkendeligt billede ud af den sorte kasse. Et råt nærbillede af en mur, en høstak eller en trækrone er praktisk talt ulæseligt. Dette "mere" som fotograferne fornemmede nødvendigheden af, er komposition, visuel syntaks, kontraster osv. osv. Fotograferne erfarede kort sagt at det fotografiske billede ikke bare er et aftryk af verden, men at det lige som alle 


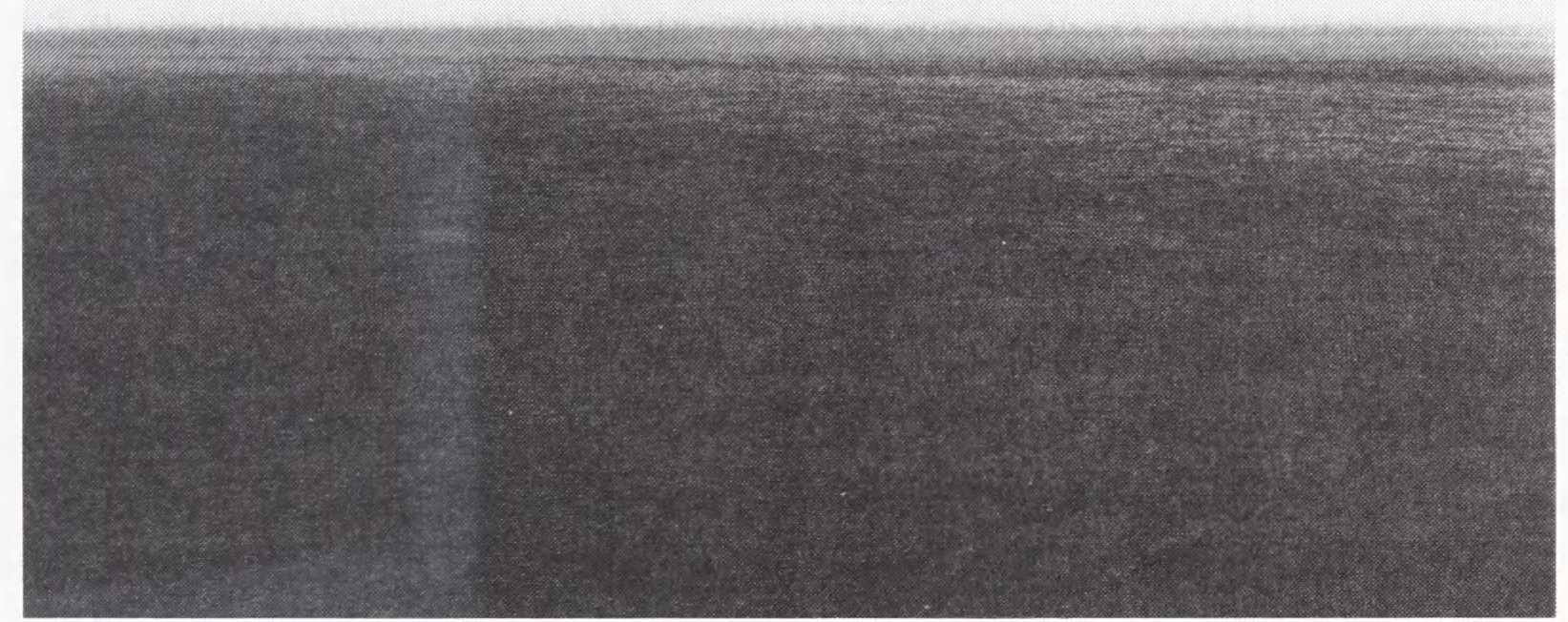

Hiroshi Sugimoto. Sea of Okhotsk, Hokkaido (D), 1989. Gelatine sølvtryk, 508 x 610 mm. 3/25.

andre billeder er en visuel konstruktion, noget menneskeskabt: Skulle det aflæses af en betragter, måtte det konstrueres over nogle af de realismekonventioner som publikum var bekendt med. Det fotografiske medium kan således forståes som en stadig udfordring til og spil med de velkendte realismekonventioner. Det må tilpasse sig disse konventioner for at opnå læsbarhed, men samtidig udfordrer det dem til stadighed. En af de grundlæggende visuelle realismekonventioner er forestillingen om at noget kommer til syne på baggrund af noget andet. Et elementært figur/grundforhold som er højt konventionaliseret og som forvaltes vidt forskelligt i forskellige visuelle kulturer. I vor kultur synes vi at prioritere figuren, dvs. den objektiverede fremtrædelse, på bekostning af grunden (som vi jo også kalder bag-grunden; det er sjældent dén, det handler om). Derfor lærer enhver fotograf også meget hurtigt at man må (skal!) placere en person, eller i det mindste en bil, foran et landskab, hvis man vil lave et "godt" landskabsbillede. Vi fascineres af objektets enhed, som Michel Serres skriver, og "foragter sanserne, fordi deres information når os i byger..."5 
Sugimotos havbil-leder bryder med alle traditionelle forestillinger om et "godt" landskabsbillede: De rummer ingen formel spænding, ingen skæve og dynamiske beskæringer, og ingen objektiverede fremtrædelser der kan etablere figur/grundforholdet. I en vis forstand har de intet motiv; de fore-stillerikke noget, for at forestille betyder at man stiller noget hen foran noget andet. Her er der intet andet end grund. Havets og himmelens ur-grund som nok danner en slags figuration, nemlig vindens krusninger på havoverfladen, men intet billede, for et billede betyder netop, som vi har set, at noget stilles frem for noget andet. Derfor gribes vi af svimmelhed over for disse vældige, tavse scenerier. Vi opsluges af dem ligesom vi opsluges af en biograffilm. ${ }^{6}$ Men tag ikke fejl: Det er ikke naturen disse fotografier viser os, men derimod verden før den blev skabt, for skabelse betyder ikke andet end at noget stilles op på baggrund af noget andet, at man skaber betydning. Sugimoto gør noget andet: Han giver os et glimt ind i det betydningsløse.

Noter

1 Se "Billedets økologi, interview med Norman

4 Kommentar efter frigivelsen af daguerreoBryson" in: Passepartout, Skrifter for kunsthistorie. Nr. 2, Århus 1993, pp. 137-145.

2 Se Thomas Kellein: Hiroshi Sugimoto. Time exposed. London 1995, p. 90.

3 Erwin Panofsky: Die Perspektive als symbolische Form. Svensk oversættelse: Perspektivet som symbolisk form. Stockholm 1994. typiet af Marc Antoine Gaudin, citeret efter Beaumont Newhall: The History of Photography. New York 1988, p. 23.

5 Michel Serres: Genese. Århus 1984, p. 13.

6 Som anført af Norman Bryson. Se "Hiroshi Sugimoto's Metabolic Photography" in: Parkett. Nr. 47, Zürich, maj 1996. 